\title{
IMPLEMENTASI UNDANG-UNDANG CIPTA KERJA TERHADAP PENYELENGGARAAN SERTIFIKASI HALAL DAN PRODUK HALAL DI INDONESIA
} (Implementation of Job Creation Law on Halal Certification and Halal Products in Indonesia)

\author{
Indah Fitriani Sukri \\ Fakultas Hukum Universitas Indonesia \\ Jl. Prof. Mr Djokosoetono, Pondok Cina, Kecamatan Beji, Kota Depok, 16424. \\ e-mail: indahfit02@gmail.com
}

\begin{abstract}
Abstrak
Proses legitimasi dari pelaksanaan Undang-Undang Nomor 33 Tahun 2014 dilaksanakan sepenuhnya oleh Badan Penyelenggara Jaminan Produk Halal dengan prinsip satu pintu untuk memudahkan pelaku usaha menerbitkan sertifikat halal. Sehingga dalam rangka pembentukan BPJPH juga perlu dikaji terkait dengan tugas, fungsi dan kewenangan dari kementerian dan lembaga terkait dengan penyelenggaraan jaminan produk halal. Tidak kurang dari USD 650 juta transaksi produk halal terjadi setiap tahunnya, dan dapat dikatakan bahwa trend halal telah terjadi dimasa kini, tujuan dari penelitian ini menganalisis implikasi UU Cipta Kerja terhadap penyelenggaraan sertifikasi halal dan produk halal. Adapun permasalahan yang diangkat dalam penelitian ini adalah keefektifan Undang-Undang Cipta Kerja terhadap penyelenggaraan sertifikasi halal dan produk halal sebagai penguatan kewenangan lembaga BPJPH yang tercantum dalam Undang Undang Cipta Kerja. Dalam penelitian ini metode penelitian menggunakan beberapa rujukan sumber hukum dengan penelitian normatif. Pembentukan BPJPH adalah bentuk upaya pemerintah memberikan perlindungan terhadap konsumen juga harus dilihat sebagai suatu sistem. Hukum sebagai suatu sistem merupakan suatu tatanan atau kesatuan yang terdiri dari bagianbagian atau unsur-unsur yang saling berkaitan, saling berinteraksi satu sama lain, yang terorganisasi dan bekerja sama untuk mencapai tujuan kesatuan itu. Maka dari itu untuk proses penerbitan sertifikat halal dibutuhkan melalui satu pintu agar semua prosesnya tidak memakan waktu lama dan pelaksanaan yang berbela belit, undang-undang tersebut juga berpotensi menimbulkan masalah kontradiksi antar peraturan, dan dominasi LPH.
\end{abstract}

Kata kunci: produk halal, sertifikasi halal, kewenangan.

\begin{abstract}
The legitimacy process of the implementation of Law Number 33 of 2014 is fully implemented by the Halal Product Guarantee Agency on the one-door principle to make it easier for business actors to issue halal certificates. So that in the framework of forming BPJPH it also needs to be studied in relation to the duties, functions and authorities of ministries and institutions related to the implementation of halal product assurance. No less than USD 650 million transactions for halal products occur every year, and it can be said that the halal trend has occurred in the present, the purpose of this study is to analyze the implications of the Job Creation Law on the implementation of halal certification and halal products. The problems raised in this study are the effectiveness of the Job Creation Law on the implementation of halal certification and halal products as a strengthening of the authority of the BPJPH institutions listed in the Job Creation Law. In this research, the research method uses several references to legal sources with normative research. The formation of BPJPH is a form of government effort to provide protection for consumers and it must also be seen as a system. Law as a system is an order or unity consisting of parts or elements that are interrelated, interact with each other, are organized and work together to achieve the goal of that unity. Therefore, the process of issuing a halal certificate is needed through one door so that all processes do not take a long time and are complicated in implementation, the law also has the potential to cause contradictions between regulations and the dominance of the LPH.
\end{abstract}

Keywords: Halal Product, Halal Certification, Authority. 


\section{A. Pendahuluan}

Sebagai negara berpenduduk muslim terbesar di dunia, Indonesia berpotensi menjadi produsen makanan halal terbesar pula. Namun, pergerakan pemasaran produk makanan halal belum mampu mengusai pasar global. Contohnya kasus pemasaran produk makanan halal ke Malaysia. Bahkan Malaysia menawarkan peluang bagi pengusaha makanan minuman Indonesia untuk masuk ke pasarnya. ${ }^{1}$

Tren industri halal menjadi perbincangan hangat di dunia bisnis internasional saat ini. Jual beli produk halal mencapai \$254 Milyar dan mendongkrak perekonomian 1-3\% GDP (Gross Domestic Product) pada negara OKI. Menurut Global Islamic Economy Report 2019/2020 Indonesia menempati posisi ke-5 dalam perkembangan industri halal. Hal tersebut sangat kontras dengan kondisi Indonesia sebagai salah satu negara yang memiliki populasi muslim terbesar yang seharusnya memiliki potensi dan kesempatan yang besar dalam industri halal. $\mathrm{Hal}$ ini menjadi sebuah tantangan untuk Indonesia dalam mengembangkan kualitas dan kuantitas dalam industri tersebut. ${ }^{2}$

Tak hanya permasalahan terkait produk makanan/minuman yang harus mempunyai logo halal. Namun dalam sudut pandang Kementerian Perindustrian jaminan halal yang diberlakukan Undang-Undang Nomor 33 Tahun 2014 berlaku untuk segala jenis barang yang beredar. Tidak hanya makanan/minuman dan obat, tetapi benda yang tergolong produk yang diperjualbelikan. ${ }^{3}$ Menurut penulis, daya tarik akan tercipta jika peluang ini dapat diambil Indonesia untuk meningkatkan daya saing pembeli domestik maupun asing. Langkah tersebut juga harus didukung pemerintah dalam menggolongkan kategori produk yang wajib sertifikasi halal.

Bagi umat Islam sendiri, mengkonsumsi makanan yang halal merupakan kewajiban untuk memenuhi perintah Allah SWT, di mana hal itu tersurat dalam Al-Quran suarat Al-Maidah ayat 88 yang artinya "Makanlah makanan yang halal lagi baik". Dengan begitu menjadi landasan utama dari dibentuknya Lembaga Pengkajian Pangan, Obat-obatan, dan Kosmetika MUI (LPPOM MUI) pada Januari 1989 sebagai upaya untuk memberikan kepastian mengenai kehalalan suatu produk pangan, obat-obatan, dan kosmetika. ${ }^{4}$

Kemudian lahir Undang-Undang Nomor 7 Tahun 1996 tentang Pangan yang telah direvisi menjadi Undang-Undang Nomor 18 Tahun 2012 tentang Pangan, di mana dalam Pasal 69 menyebutkan bahwa salah satu penyelenggaraan keamanan pangan dilakukan melalui jaminan produk halal bagi yang dipersyaratkan, dan ketentuan mengenai pencantuman label halal pada kemasan produk dijelaskan dalam Pasal 97 UU tersebut. Lebih lanjut secara detail, labelisasi halal juga diatur dalam Peraturan Pemerintah Nomor 69 Tahun 1999 tentang Label dan Iklan Pangan. Dalam PP tersebut, Badan Standarisasi Nasional (BSN) merupakan lembaga yang

1 "Produk Halal RI Belum Mendominasi", (https://kemenperin.go.id/artikel, diakses 29/05/2021)

2 "Hambatan dan Stategi Pengembangan Industri Halal di Indonesia", (http://news.unair.ac.id/2020/09/09/hambatandan-strategi-pengembangan-industri-halal-di-indonesia/, diakses 29/05/2021).

3 "Masalah yang Timbul Jika Semua Produk Wajib Diberi Label Halal", (https://tirto.id/masalah-yang-timbul-jika-semuaproduk-wajib-diberi-label-halal-ejrk, diakses 28/05/2021).

4 "Waketum MUI: Kewajiban menjaga Fitrah dengan Konsumsi Halal", (https://www.halalmui.org/mui14/main/detail/ waketum-mui-kewajiban-menjaga-fitrah-dengan-konsumsi-halal, diakses 20/04/2021) 
melakukan akreditasi terhadap lembaga pemeriksa yang akan memeriksa kebenaran pernyataan halal yang akan dicantumkan pada label suatu produk pangan. Dengan dasar inilah BSN membentuk suatu tim pengembangan akreditasi. Lembaga Sertifikasi Halal pada tahun 2001 yang anggotanya merupakan perwakilan dari Kementerian Pertanian, Badan Pengawas Obat dan Makanan (BPOM), Kementerian Perdagangan, Kementerian Agama, Asosiasi Industri Pangan, YLKI dan Yayasan Lembaga Konsumen Muslim, Perguruan Tinggi, LPPOM MUI, dan BSN sendiri. ${ }^{5}$

Kehadiran peraturan yang ada sebelumnya memang menyinggung masalah Jaminan Produk Halal (JPH) namun dinilai masih ambiguous. Maka pada tahun 2006, DPR RI melalui usul inisiatif mengusulkan RUU tentang Jaminan Produk Halal. Setelah delapan tahun melalui pembahasan, akhirnya pada tahun 2014 RUU tersebut disahkan menjadi Undang-Undang No. 33 Tahun 2014 tentang Jaminan Produk Halal, harapannya dapat memberikan kepastian hukum bagi konsumen, khususnya konsumen muslim.

Sebagaimana tugas atau wewenang dari Badan Penyelenggara Jaminan Produk Halal (BPJPH) merupakan sebuah badan yang terbentukdibawah naungan Kementerian Agama (KEMENAG), diatur dalam Undang-undang No. 33 Tahun 2014 tentang Jaminan Produk Halal salah satunya adalah mengamanatkan agar produk yang beredar di Indonesia terjamin kehalalannya oleh sebab itu BPJPH dalam menyelenggarakan tugas dan fungsinya untuk menjamin kehalalan produk yang masuk, beredar, hingga diperdagangkan di Indonesia.
Selain itu, tugas dan fungsinya registrasi halal, sertifikasi halal, verifikasi halal, melakukan pembinaan serta melakukan pengawasan kehalalan produk, kerjasama dengan seluruh stakeholder terkait, serta menetapkan kehalalan sebuah produk. Namun sejalan dengan itu terjadi persinggungan kewenangan, seperti yang disampaikan oleh Sukoso "Sesuai amanat Undang-Undang Nomor 33 Tahun 2014 Tentang Jaminan Produk Halal, Pasal 6, salah satu dari 10 kewenangan BPJPH adalah mengeluarkan dan mencabut sertifikasi halal dan label halal pada produk. Sedang MUI, sebagaimana diatur dalam Pasal 10, berwenang dalam memberikan fatwa kehalalan produk". Hal ini berarti pemberian sertifikasi halal adalah kewenangan Kemenag, serta BPJPH berwenang dalam pengajuan permohonan dan penerbitan sertifikasi halal, MUI berwenang dalam pelaksanaan fatwa halal, LPH berwenang dalam pemeriksaan dan atau pengujian kehalalan produk. Proses, tahapan dan kewenangan terkait sertifikasi halal diatur juga dalam Peraturan Menteri Agama No. 26 Tahun 2019 Tentang Penyelenggaraan Jaminan Produk Halal.

Menurut J. N. D. Anderson tiga sikap itu menjadi ciri umum dunia Islam dalam penerapan syariah. Tiga sikap dunia Islam ini sejalan dengan sikap masyarakat Indonesia dalam menyikapi syariah dalam negara. Sikap ini jelas tidak terhindar dari polemik dan kepentingan politik dalam menentukan posisi syariah dalam negara. Bahkan jika dilihat dari teori sosial khususnya critical theory, polemik itu tidak bisa dilepaskan dari kepentingan politik penguasa, masyarakat, dan elite politik. Perbedaan paradigma pemikiran itu terlihat jelas ketika terjadi interaksi antara 
pusat-pusat kekuasaan (power points) baik di tingkat inprastruktur maupun suprastruktur di tengah-tengah masyarakat seperti partai politik, pemerintah, $A B R I$, ormas keagamaan/lembaga swadaya masyarakat, masyarakat muslim dan non-muslim serta media massa dalam proses legislasi hukum Islam di Indonesia.

Amanat Undang-Undang No. 33 Tahun 2014 tentang Jaminan Produk Halal dilaksanakan mulai tanggal 17 Oktober 2019, Jaminan Produk Halal akan mulai diselenggarakan oleh pemerintah melalui Badan Penyelenggara Jaminan Produk Halal (BPJPH) Kementerian Agama. Hal ini sesuai dengan amanat Undang-Undang No. 33 Tahun 2014 tentang Jaminan Produk Halal. Pemberlakukan kewajiban sertifikasi halal mulai 17 Oktober 2019 dilakukan secara bertahap. ${ }^{6}$

Undang-Undang Nomor 33 Tahun 2014 tentang Jaminan Produk Halal ada untuk menjamin kepastian hukum tentang penjaminan produk halal. Undang-Undang Nomor 33 Tahun 2014 tentang Jaminan Produk Halal disahkan Presiden Dr. H. Susilo Bambang Yudhoyono di Jakarta pada tanggal 17 Oktober 2014. UndangUndang Nomor 33 Tahun 2014 tentang Jaminan Produk Halal mulai berlaku sejak diundangkan pada tanggal 17 Oktober 2014 oleh Menkumham Amir Syamsudin, di Jakarta. ${ }^{7}$

Undang-Undang Nomor 33 Tahun 2014 tentang Jaminan Produk Halal didalamnya mengatur tentang: untuk menjamin ketersediaan Produk Halal, ditetapkan bahan produk yang dinyatakan halal, baik bahan yang berasal dari bahan baku hewan, tumbuhan, mikroba, maupun bahan yang dihasilkan melalui proses kimiawai, proses biologi, atau proses rekayasa genetik. Di samping itu, ditentukan pula Proses Produk Halal (PPH) yang merupakan rangkaian kegiatan untuk menjamin kehalalan Produk yang mencakup penyediaan bahan, pengolahan, penyimpanan, pengemasan, pendistribusian, penjualan, dan penyajian Produk. ${ }^{8}$

Undang-Undang ini mengatur hak dan kewajiban Pelaku Usaha dengan memberikan pengecualian terhadap Pelaku Usaha yang memproduksi Produk dari Bahan yang berasal dari Bahan yang diharamkan dengan kewajiban mencantumkan secara tegas keterangan tidak halal pada kemasan Produk atau pada bagian tertentu dari Produk yang mudah dilihat, dibaca, tidak mudah terhapus, dan merupakan bagian yang tidak terpisahkan dari Produk. ${ }^{9}$

Dalam rangka memberikan pelayanan publik, Pemerintah bertanggung jawab dalam menyelenggarakan JPH yang pelaksanaannya dilakukan oleh BPJPH. Dalam menjalankan wewenangnya, BPJH bekerja sama dengan kementerian dan/atau lembaga terkait, MUI, dan $\mathrm{LPH}{ }^{10}$

Biaya sertifikasi halal dibebankan kepada Pelaku Usaha yang mengajukan permohonan Sertifikat Halal. Dalam rangka memperlancar pelaksanaan penyelenggaraan JPH, UndangUndang ini memberikan peran bagi pihak lain seperti Pemerintah melalui anggaran pendapatan dan belanja negara, pemerintah daerah melalui anggaran pendapatan dan belanja daerah, perusahaan, lembaga sosial,

6 "Jaminan Produk Halal", (https://www.jogloabang.com/pustaka/uu-33-2014-jaminan-produk-halal, diakses 20/3/2020).

7 Ibid

8 Ibid

9 Ibid

10 Pasal 7 Undang-Undang Nomor 33 Tahun 2014 tentang Jaminan Produk Halal 
lembaga keagamaan, asosiasi, dan komunitas untuk memfasilitasi biaya sertifikasi halal bagi pelaku usaha mikro dan kecil. ${ }^{11}$ Jika beban biaya ini harus ditanggung oleh pelaku usaha maka lebih ideal kewenangan tersebut dijalankan oleh lembaga negara bentukan kementerian Agama berdasarkan dengan Undang-undang No. 33 Tahun 2014, jika kewenangan tersebut harus dipegang oleh organisasi masyarakat yang berbadan hukum dan akan berakhir pada ketimpangan wewenang.

Untuk menjamin penegakan hukum terhadap pelanggaran Undang-Undang ini, ditetapkan sanksi administratif dan sanksi pidana. Undang-Undang Nomor 33 Tahun 2014 tentang Jaminan Produk Halal. Latar Belakang Pertimbangan pengesahan UndangUndang Nomor 33 Tahun 2014 tentang Jaminan Produk Halal adalah: bahwa Undang-Undang Dasar Negara Republik Indonesia Tahun 1945 mengamanatkan negaramenjamin kemerdekaan tiap-tiap penduduk untuk memeluk agamanya masing-masing dan untuk beribadah menurut agamanya dan kepercayaannya itu; bahwa untuk menjamin setiap pemeluk agama untuk beribadah dan menjalankan ajaran agamanya, negara berkewajiban memberikan pelindungan dan jaminan tentang kehalalan produk yang dikonsumsi dan digunakan masyarakat; bahwa produk yang beredar di masyarakat belum semua terjamin kehalalannya; bahwa pengaturan mengenai kehalalan suatu produk pada saat ini belum menjamin kepastian hukum dan perlu diatur dalam suatu peraturan perundangundangan; bahwa berdasarkan pertimbangan sebagaimana dimaksud dalam huruf $a$, huruf $b$, huruf c, dan huruf d perlu membentuk UndangUndang tentang Jaminan Produk Halal. ${ }^{12}$

Untuk menjamin setiap pemeluk agama beribadah dan menjalankan ajaran agamanya, negara berkewajiban memberikan pelindungan dan jaminan tentang kehalalan produk yang dikonsumsi dan digunakan masyarakat. Jaminan mengenai Produk Halal hendaknya dilakukan sesuai dengan asas pelindungan, keadilan, kepastian hukum, akuntabilitas dan transparansi, efektivitas dan efisiensi, serta profesionalitas. Oleh karena itu, jaminan penyelenggaraan Produk Halal bertujuan memberikan kenyamanan, keamanan, keselamatan, dan kepastian ketersediaan Produk Halal bagi masyarakat dalam mengonsumsi dan menggunakan produk, serta meningkatkan nilai tambah bagi Pelaku Usaha untuk memproduksi dan menjual Produk Halal. ${ }^{13}$

Tujuan tersebut menjadi penting mengingat kemajuan ilmu pengetahuan dan teknologi di bidang pangan, obat-obatan, dan kosmetik berkembang sangat pesat. Hal itu berpengaruh secara nyata pada pergeseran pengolahan dan pemanfaatan bahan baku untuk makanan, minuman, kosmetik, obat-obatan, serta produk lainnya dari yang semula bersifat sederhana dan alamiah menjadi pengolahan dan pemanfaatan bahan baku hasil rekayasa ilmu pengetahuan. Pengolahan produk dengan memanfaatkan kemajuan ilmu pengetahuan dan teknologi memungkinkan percampuran antara yang halal dan yang haram baik disengaja maupun tidak disengaja. Oleh karena itu, untuk mengetahui kehalalan dan kesucian suatu produk, diperlukan suatu kajian khusus yang membutuhkan 
pengetahuan multidisiplin, seperti pengetahuan di bidang pangan, kimia, biokimia, teknik industri, biologi, farmasi, dan pemahaman tentang syariat.

Berdasarkan hal tersebut, maka pokok permasalahan yang menjadi fokus pembahasan adalah; (1) Bagaimana Undang-Undang Cipta Kerja mengatur kewenangan antara Badan Penyelenggara Jaminan Produk Halal (BPJPH) dengan MUI (Majelis Ulama Indonesia), (2) Bagaimana UU Cipta Kerja mengatur proses penerbitan sertifikasi halal.

\section{B. Metode Penelitian}

Pembagian penelitian hukum yang utama yaitu pembagian kepada (1) metode penelitian hukum yang normatif, yang ada prinsipnya melakukan penelitian terhadap kaidah hukum dalam perundang-undangan, yurisprudensi dan doktrin, yang dilakukan secara kualitatif, dan (2) metode penelitian hukum empiris, yang memandang hukum sebagai fenomena sosial sehingga lebih meneliti hukum dalam masyarakat baik dilakukan secara kualitatif maupun secara kuantitatif. Dalam praktik metode penelitian hukum normatif lebih banyak digunakan karena dianggap merupakan penelitian hukum yang empiris, meskipun sebenarnya lebih merupakan penelitian sosilogis. ${ }^{14}$

Metode yang digunakan dalam kajian ini adalah metode deskriptif kualitatif. Deskriptif kualitatif mengacu pada identifikasi sifatsifat yang membedakan atau karakteristik sekelompok manusia, benda, dan peristiwa. Pada dasarnya, deskriptif kualitatif melibatkan proses konseptualisasi dan menghasilkan pembentukan skema-skema klasifikasi. ${ }^{15}$ Data yang digunakan adalah data sekunder yang bersumber dari publikasi yaitu buku-buku, jurnal, surat kabar, website, serta dokumen kebijakan yang berkaitan dengan permasalahan.

Berkaitan dengan itu, dalam realitasnya banyak produk yang beredar di masyarakat belum semua terjamin kehalalannya. Sementara itu, berbagai peraturan perundang-undangan yang memiliki keterkaitan dengan pengaturan Produk Halal belum memberikan kepastian dan jaminan hukum bagi masyarakat muslim. Oleh karena itu, pengaturan mengenai JPH perlu diatur dalam satu undang-undang yang secara komprehensif mencakup produk yang meliputi barang dan/atau jasa yang terkait dengan makanan, minuman, obat, kosmetik, produk kimiawi, produk biologi, dan produk rekayasa genetik serta barang gunaan yang dipakai, digunakan, atau dimanfaatkan oleh masyarakat. Berdasarkan hal tersebut, maka penulis akan melakukan penelitian mengenai "IMPLEMENTASI UNDANG-UNDANG CIPTA KERJA TERHADAP PENYELENGGARAAN SERTIFIKASI HALAL DAN PRODUK HALAL DI INDONESIA".

\section{Pembahasan}

1. Kewenangan Kelembagaan BPJPH dan MUI (Melalui LPPOM MUI)

Pengaturan pemeriksaan sertifikasi halal pada awalnya merupakan kewenangan dari Kementerian Agama. ${ }^{16}$ Kementerian Agama telah mengeluarkan Keputusan Menteri Agama No. 518 Tahun 2001 tentang Pedoman dan Tata Cara Pemeriksaan dan Penetapan Pangan

14 Munir Fuadi, Metode Riset Hukum Pendekatan Teori dan Konsep, (Depok: Rajawali Press, Cet 2018), hlm. 20.

15 Ulber Silalahi, Metode Penelitian Sosial, (Bandung: Refika Aditama, 2010), hlm. 27-28.

16 Pasal 11 ayat (2) Peraturan Pemerintah No. 69 Tahun 1999 Tentang Label Iklan Pangan (Lembaran Negara Republik Indonesia Tahun 1999 Nomor 131, Tambahan Lembaran Negara Republik Indonesia Nomor 3867). 
Halal. Selanjutnya ditindaklanjuti dengan Keputusan Menteri Agama No. 519 Tahun 2001 tentang Lembaga Pelaksana Pemeriksa Pangan Halal, yang menunjuk dan mendelegasikan pelaksanaan sertifikasi halal ke Lembaga Pengkajian Pangan Obat Obatan dan Kosmetika Majelis Ulama Indonesia (LPPOM-MUI).

Dalam perkembangannya, pengaturan sertifikasi halal selama ini masih terkesan sektoral, parsial, inkonsistensi sertatidaksistemik dan sukarela (voluntery), yang mengakibatkan sertifikasi halal belum mempunyai legitimasi hukum yang kuat. ${ }^{17}$ Selain itu masih banyak produk yang beredar di masyarakat belum semua terjamin kehalalannya, sehingga memerlukan pengaturan yang komprehensif yang meliputi produk barang dan jasa. ${ }^{18}$ Berdasarkan faktor tersebut maka penyelenggaraan sertifikasi halal diatur dalam Undang-Undang Nomor 33 Tahun 2014 Tentang Jaminan Produk Halal (UUJPH).

BPJPH dalam penyelenggaraan jaminan produk halal diberikan kewenangan untuk menerbitkan dan mencabut sertifikasi halal dan label halal pada produk. Kewenangan ini sebelumnya dilaksanakan oleh LPPOM-MUI. Yang berarti bahwa pemberlakuan UUJPH ini secara kelembagaan nantinya akan terjadi peralihan kewenangan dalam hal penerbitan sertifikasi halal dari LPPOM-MUI kepada BPJPH. Sertifikasi halal merupakan pengakuan kehalalan suatu produk yang dikeluarkan oleh BPJPH berdasarkan fatwa halal tertulis yang dikeluarkan oleh MUI.

Pembentukan BPJPH adalah bentuk upaya pemerintah memberikan perlindungan terhadap konsumen juga harus dilihat sebagai suatu sistem. Hukum sebagai suatu sistem merupakan suatu tatanan atau kesatuan yang terdiri dari bagian-bagian atau unsur-unsur yang saling berkaitan, saling berinteraksi satu sama lain, yang terorganisasi dan bekerja sama untuk mencapai tujuan kesatuan itu. Hukum bukanlah sekadar sekumpulan hukum yang masingmasing berdiri sendiri, tetapi harus dilihat dalam kaitannya dengan bagian-bagian lain dalam sistem tersebut. ${ }^{19}$

Peraturan perundang-undangan yang terkait dengan sertifikasi halal ini diatur dalam beberapa ketentuan perundang-undangan sehingga dalam rangka pembentukan $\mathrm{BPJPH}$ perlu juga dilaksanakan harmonisasi dan sinkronisasi dengan peraturan perundangundangan terkait. Harmonisasi peraturan perundang-undangan merupakan suatu proses mencari kesesuaian antara peraturan perundang-undangan. Harmonisasi ini idealnya dilakukan pada saat perancangan peraturan perundang-undangan. Adapun sinkronisasi merupakan penyelerasan dan penyelerasian berbagai peraturan perundang-undangan yang terkait dengan peraturan perundang-undangan yang telah ada dan yang sedang disusun yang mengatur suatu bidang tertentu, sinkronisasi dilakukan agar substansi yang diatur dalam produk perundang-undangan tidak tumpang tindih, saling melengkapi (suplementer), saling terkait, dan semakin rendah jenis pengaturannya maka semakin detail dan operasional materi

17 KN Sofyan Hasan, Kepastian Hukum Sertifikasi dan Labelisasi Halal Produk Pangan, Dinamika Hukum, Volume 14, Nomor 2, Mei 2014

18 Penjelasan Umum Undang-Undang Nomor 33 Tahun 2014 Tentang Jaminan Produk Halal (Lembaran Negara Republik Indonesia Nomor 295, Tambahan Lembaran Negara Republik Indonesia Nomor 5604).

19 Sudikno Mertokusumo, Penemuan Hukum: Sebuah Pengantar, Yogyakarta: Liberty, 2006, hlm. 18. 
muatannya. ${ }^{20}$ Sinkronisasi dilakukan meliputi sinkronisasi vertikal yaitu mengidentifikasikan apakah suatu perundang-undangan tersebut sejalan apabila ditinjau dari sudut strata atau hierarki peraturan perundangan yang ada, dan sinkronisasi horizontal yakni mengidentifikasi peraturan perundang-undangan yang kedudukannya sederajat dan yang mengatur bidang yang sama. ${ }^{21}$

Undang-Undang Nomor 33 Tahun 2014 tentang Jaminan Produk Halal didalamnya mengatur tentang: untukmenjamin ketersediaan Produk Halal, ditetapkan bahan produk yang dinyatakan halal, baik bahan yang berasal dari bahan baku hewan, tumbuhan, mikroba, maupun bahan yang dihasilkan melalui proses kimiawai, proses biologi, atau proses rekayasa genetik. Di samping itu, ditentukan pula PPH yang merupakan rangkaian kegiatan untuk menjamin kehalalan Produk yang mencakup penyediaan bahan, pengolahan, penyimpanan, pengemasan, pendistribusian, penjualan, dan penyajian Produk. ${ }^{22}$ Undang-Undang ini mengatur hak dan kewajiban Pelaku Usaha dengan memberikan pengecualian terhadap Pelaku Usaha yang memproduksi Produk dari Bahan yang berasal dari Bahan yang diharamkan dengan kewajiban mencantumkan secara tegas keterangan tidak halal pada kemasan Produk atau pada bagian tertentu dari Produk yang mudah dilihat, dibaca, tidak mudah terhapus, dan merupakan bagian yang tidak terpisahkan dari Produk. ${ }^{23}$

Untuk menjamin penegakan hukum terhadap pelanggaran Undang-Undang ini, ditetapkan sanksi administratif dan sanksi pidana. Undang-Undang Nomor 33 Tahun 2014 tentang Jaminan Produk Halal. Latar Belakang Pertimbangan pengesahan UndangUndang Nomor 33 Tahun 2014 tentang Jaminan Produk Halal adalah: bahwa Undang-Undang Dasar Negara Republik Indonesia Tahun 1945 mengamanatkan negara menjamin kemerdekaan tiap-tiap penduduk untuk memeluk agamanya masing-masing dan untuk beribadah menurut agamanya dan kepercayaannya itu; bahwa untuk menjamin setiap pemeluk agama untuk beribadah dan menjalankan ajaran agamanya, negara berkewajiban memberikan pelindungan dan jaminan tentang kehalalan produk yang dikonsumsi dan digunakan masyarakat; bahwa produk yang beredar di masyarakat belum semua terjamin kehalalannya; bahwa pengaturan mengenai kehalalan suatu produk pada saat ini belum menjamin kepastian hukum dan perlu diatur dalam suatu peraturan perundangundangan; bahwa berdasarkan pertimbangan sebagaimana dimaksud dalam huruf $a$, huruf $b$, huruf $c$, dan huruf d perlu membentuk UndangUndang tentang Jaminan Produk Halal. ${ }^{24}$

Penyelenggaraan seritifikasi halal yang selama ini telah dilaksanakan oleh LPPOM-MUI dilaksanakan kerjasama dengan kementerian dan lembaga terkait. ${ }^{25}$ Sehingga dalam rangka pembentukan BPJPH juga perlu dikaji terkait dengan tugas, fungsi dan kewenangan dari kementerian dan lembaga terkait dengan penyelenggaraan jaminan produk

20 Novianto M Hantoro, Sinkronisasi dan Harmonisasi Pengaturan Mengenai Peraturan Daerah Serta Uji Materi Peraturan Daerah Provinsi Bali Nomor 16 Tahun 2009 Tentang Tata Ruang Wilayah Provinsi Bali Tahun 2009-2029.

21 Zaidah Nur Rosidah, Sinkronisasi Peraturan Perundang-Undangan Mengenai Perkawinan Beda Agama, Al-Ahkam, Volume 23, Nomor 1, April 2013.

22 Undang-undang Nomor 33 Tahun 2014 tentang Jaminan Produk Halal https://www.jogloabang.com/pustaka/uu-332014-jaminan-produk-halal diakses pada 18/05/2020

23 Ibid

24 Ibid

25 “Majelis Ulama Indonesia, Tentang LPPOM-MUI”, (http://www.halalmui.org/mui14/ diakses 18/05/2020). 
halal. Berdasarkan dari uraian diatas maka permasalahan yang diambil yakni bagaimana penyelenggaraan sertifikasi halal di Indonesia terkait Undang-Undang Nomor 33 Tahun 2014 tentang Jaminan Produk Halal (UUJPH) serta bagaimana penguatan lembaga BPJPH dalam menjalankan kewenangannya.

Kewenangan BPJPH dalam Undang Undang Nomor 33 Tahun 2014

Berdasarkan Pasal 6 Undang-Undang Nomor 33 Tahun 2014, dalam penyelenggaraan JPH, BPJPH berwenang;

a. Merumuskan dan menetapkan kebijakan $\mathrm{JPH}$;

b. Menetapkan norma, standar, prosedur, dan kriteria JPH;

c. Menerbitkan dan mencabut Sertifikat Halal dan Label Halal pada produk;

d. Melakukan registrasi Sertifikat Halal pada Produk luar negeri;

e. Melakukan sosialisasi, edukasi, dan publikasi Produk Halal;

f. Melakukan akreditasi terhadap LPH;

g. Melakukan registrasi Auditor Halal;

h. Melakukan pengawasan terhadap JPH;

i. Melakukan pembinaan Auditor Halal; dan j. Melakukan kerja sama dengan lembaga dalam dan luar negeri di bidang penyelenggaraan JPH.

Dalam melaksanakan tugasnya BPJPH melakukan pengawasan terhadap JPH, pengawasan JPH dilakukan terhadap LPH; masa berlaku Sertifikat Halal; kehalalan produk; pencantuman Label Halal; pencantuman keterangan tidak halal; pemisahan lokasi, tempat dan alat penyembelihan, pengolahan, penyimpanan, pengemasan, pendistribusian, penjualan, serta penyajian antara Produk Halal dan tidak halal; keberadaan Penyelia Halal; dan/ atau kegiatan lain yang berkaitan dengan JPH.

Masyarakat dapat berperan serta dalam penyelenggaraan JPH. Peran serta masyarakat dapat berupa: melakukan sosialisasi mengenai JPH; dan mengawasi Produk dan Produk Halal yang beredar berbentuk pengaduan atau pelaporan ke BPJPH. Menururt penulis, ada beberapa hal yang musti diperhatikan dalam menjalankan pelaksanaan sertfikasi halal selain penjaminan kepastian unsur halal suatu produk, juga kemudahan memperoleh sertifikat halal bagi pelaku usaha.

Tabel. 1. Perbandingan Penyelenggaraan Jaminan Produk Halal

\begin{tabular}{|c|c|}
\hline Penyelenggaraan JPH oleh LPPOM MUI & Penyelenggaraan JPH Sesuai UU JPH \\
\hline $\begin{array}{l}\text { Kekuatan: } \\
\text { - Infrastruktur dan sistem telah terbentuk, bahkan } \\
\text { permohonan sertifikasi halal bisa dilakukan secara } \\
\text { on-line; } \\
\text { - Ulama memiliki otoritas penuh dalam sertifikasi } \\
\text { halal; } \\
\text { - Alur birokrasi pendek karena penyelenggaraan oleh } \\
1 \text { (satu) lembaga; } \\
\text { - Sudah memiliki pengalaman termasuk dengan luar } \\
\text { negeri; } \\
\text { - Memiliki aspek historis dalam penjaminan } \\
\text { produk halal dan bersifat subsidi silang serta tidak } \\
\text { membebani APBN/APBD. }\end{array}$ & $\begin{array}{l}\text { Kekuatan: } \\
\text { - Penyelenggaraan JPH dan keberadaan LPH } \\
\text { terorganisasi; } \\
\text { - BPJPH memiliki kekuatan hukum karena dibentuk } \\
\text { atas dasar perintah UU; } \\
\text { - Sertifikat halal merupakan kewajiban bagi pelaku } \\
\text { usaha; } \\
\text { - Adanya dukungan APBN/APBD bagi pengusaha } \\
\text { mikro dan kecil; } \\
\text { - Adanya pendapatan bagi negera dalam bentuk } \\
\text { penerimaan negara bukan pajak dari biaya } \\
\text { permohonan sertifikat halal; } \\
\text { - Masa berlaku sertifikat halal selama } 4 \text { tahun. }\end{array}$ \\
\hline
\end{tabular}




\section{Kelemahan:}

- Tidak memiliki payung hukum yang kuat;

- Sertifikasi halal bukan suatu kewajiban bagi pelaku usaha (voluntary);

- Kapasitas/kemampuan pemeriksaan terbatas;

- Dukungan anggaran, sarana prasarana, dan SDM dari negara terbatas;

- Pengawasan dan penegakan hukum lemah;

- Tidak ada pendapatan yang masuk ke negara dari biaya permohonan sertifikasi halal;

- Masa berlaku sertifikat halal selama 2 tahun.

\section{Kelemahan:}

- Memerlukan waktu dan biaya untuk pembentukan infrastruktur yang baru, baik di pusat, provinsi, dan kabupaten/kota;

- Membutuhkan waktu untuk menyiapkan sumber daya manusia bagi BPJPH;

- Alur proses menjadi panjang dan birokratis karena banyak pihak/lembaga yang terlibat;

- Rawan konflik kepentingan antara LPH pemerintah dan LPH swasta, begitu juga antara MUI dengan LPPOM MUI yang akan menjadi salah satu LPH;

- Pelaku usaha tetap dikenakan biaya walaupun seharusnya menjadi kewajiban pemerintah untuk memberikan jaminan kehalalan produk;

- Masih perlu diatur akuntabilitas dan transparansi kinerjanya;

- Membutuhkan peraturan-peraturan turunan dari UU (peraturan pemerintah dan peraturan menteri) dalam penyelenggaraannya.

Sumber: diolah penulis, 2020.

Untuk menjamin setiap pemeluk agama beribadah dan menjalankan ajaran agamanya, negara berkewajiban memberikan pelindungan dan jaminan tentang kehalalan Produk yang dikonsumsi dan digunakan masyarakat. Jaminan mengenai Produk Halal hendaknya dilakukan sesuai dengan asas pelindungan, keadilan, kepastian hukum, akuntabilitas dan transparansi, efektivitas dan efisiensi, serta profesionalitas. Oleh karena itu, jaminan penyelenggaraan Produk Halal bertujuan memberikan kenyamanan, keamanan, keselamatan, dan kepastian ketersediaan Produk Halal bagi masyarakat dalam mengonsumsi dan menggunakan Produk, serta meningkatkan nilai tambah bagi Pelaku Usaha untuk memproduksi dan menjual Produk Halal.

Tujuan tersebut menjadi penting mengingat kemajuan ilmu pengetahuan dan teknologi di bidang pangan, obat-obatan, dan kosmetik berkembang sangat pesat. Hal itu berpengaruh secara nyata pada pergeseran pengolahan dan pemanfaatan bahan baku untuk makanan, minuman, kosmetik, obat-obatan, serta Produk lainnya dari yang semula bersifat sederhana dan alamiah menjadi pengolahan dan pemanfaatan bahan baku hasil rekayasa ilmu pengetahuan. Pengolahan produk dengan memanfaatkan kemajuan ilmu pengetahuan dan teknologi memungkinkan percampuran antara yang halal dan yang haram baik disengaja maupun tidak disengaja. Oleh karena itu, untuk mengetahui kehalalan dan kesucian suatu Produk, diperlukan suatu kajian khusus yang membutuhkan pengetahuan multidisiplin, seperti pengetahuan di bidang pangan, kimia, biokimia, teknik industri, biologi, farmasi, dan pemahaman tentang syariat.

Berkaitan dengan itu, dalam realitasnya banyak Produk yang beredar di masyarakat belum semua terjamin kehalalannya. Sementara itu, berbagai peraturan perundang-undangan yang memiliki keterkaitan dengan pengaturan Produk Halal belum memberikan kepastian dan jaminan hukum bagi masyarakat muslim. Oleh karena itu, pengaturan mengenai JPH 
perlu diatur dalam satu undang-undang yang secara komprehensif mencakup Produk yang meliputi barang dan/atau jasa yang terkait dengan makanan, minuman, obat, kosmetik, produk kimiawi, produk biologi, dan produk rekayasa genetik serta barang gunaan yang dipakai, digunakan, atau dimanfaatkan oleh masyarakat. Serta pengaturan mengenai sumber kewenangan dari tiap-tiap lembaga. Menurut penulis, diperlukan hanya satu lembaga yang berwenang mengeluarkan dan mencabut izin sertifikasi halal dengan metode satu pintu, jika terlalu banyak lembaga atau instansi yang diberikan kewenangan yang sama maka sama saja halnya penerbitan sertifikasi halal ini tidak transparan dan berpotensi menimbulkan masalah, apalagi menyangkut audit anggaran akan berakibat pada penyakit korupsi.

\section{a. Jaminan Produk Halal dalam Undang- Undang Nomor 11 Tahun 2020 tentang Cipta Kerja}

Beberapa ketentuan yang ada dalam undang undang sebelumnya kemudian diatur dalam Pasal 48 Undang-Undang Nomor 11 Tahun 2020 tentang Cipta Kerja terkait jaminan produk halal, sebagai berikut;

Pada Pasal 4A, berbunyi

“(1) untuk Pelaku Usaha Mikro dan Kecil, kewajiban bersertifikat halal sebagaimana dimaksud dalam Pasal 4 didasarkan atas pernyataan pelaku usaha Mikro dan Kecil. (2) Pernyataan Pelaku Usaha Mikro dan Kecil sebagaimana dimaksud pada ayat (1) dilakukan berdasarkan standar halal yang ditetapkan oleh BPJPH".

Ketentuan Pasal 10 diubah;

“(1) kerja sama BPJPH dengan MUI sebagaimana dimaksud dalam Pasal 7 huruf c dilakukan dalam hal penetapan kehalalan produk. (2) Penetapan kehalalan Produk sebagaimana dimaksud pada ayat (1) diterbitkan MUI dalam bentuk Keputusan Penetapan Halal Produk".

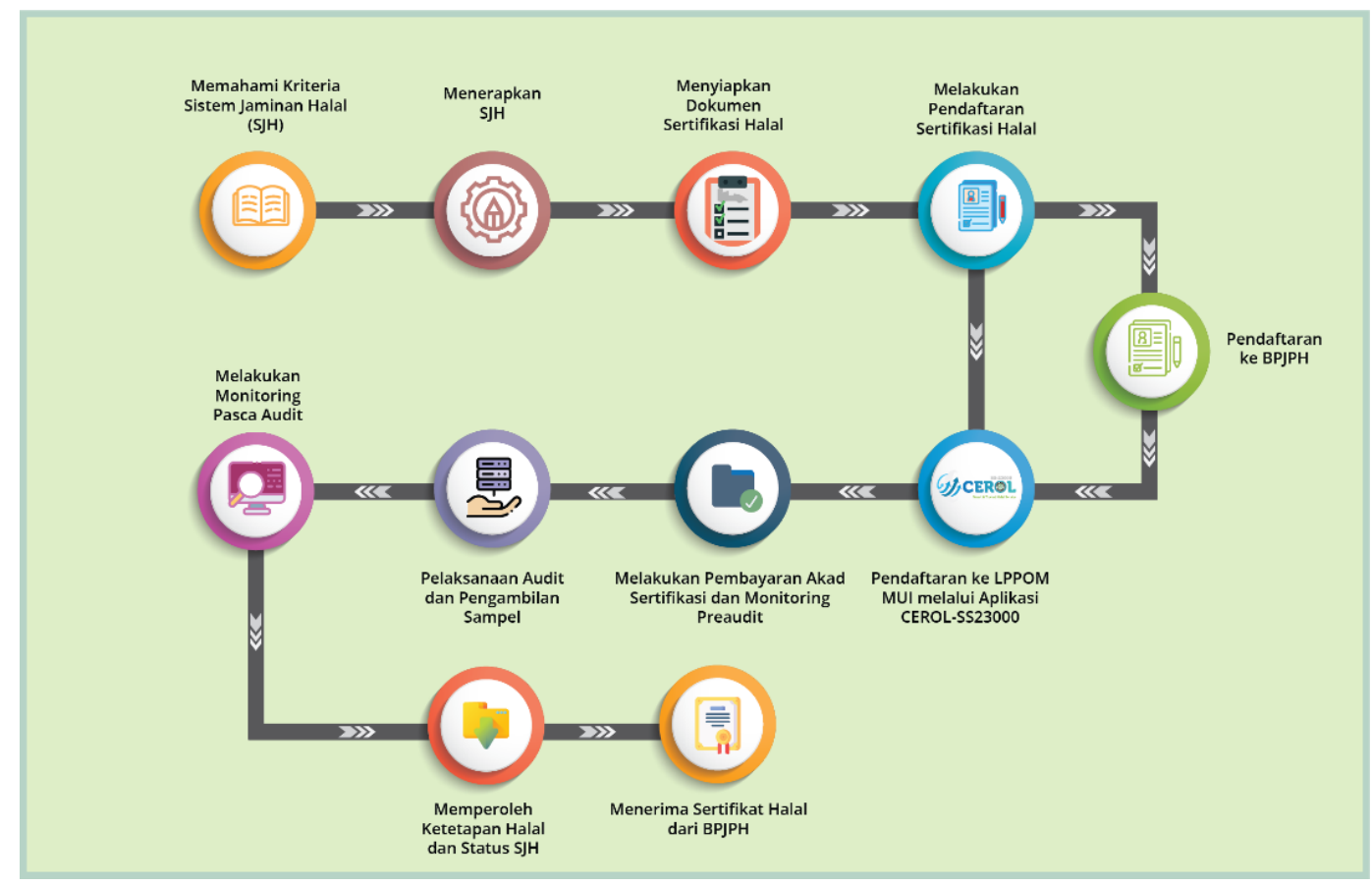


Berikut alur atau proses persiapan sertifikasi dan pendaftaran sertifikasi: ${ }^{26}$

1. Memahami Kriteria Sistem Jaminan Halal. Perusahaan dapat mengikuti pelatihan yang diadakan lembaga pelatihan terkait Sistem Jaminan Halal (SJH)

2. Menerapkan Sistem Jaminan Halal dan Menyiapkan Dokumen Pendaftaran.

3. Melakukan Pendaftaran Sertifikasi Halal (Upload Data). Perusahaan perlu melakukan pendaftaran terlebih dahulu ke BPJPH untuk memperoleh surat pengantar yang nantinya diperlukan untuk pendaftaran sertifikasi halal ke LPPOM MUI. Pendaftaran sertifikasi halal ke LPPOM MUI dapat dilakukan secara pararel dengan pendaftaran ke BPJPH. Pendaftaran ke LPPOM MUI dilakukan secara online menggunakan sistem Cerol melalui website www.e-lppommui.org.

Berikut jalannya proses layanan sertifikasi halal di halal.go.id

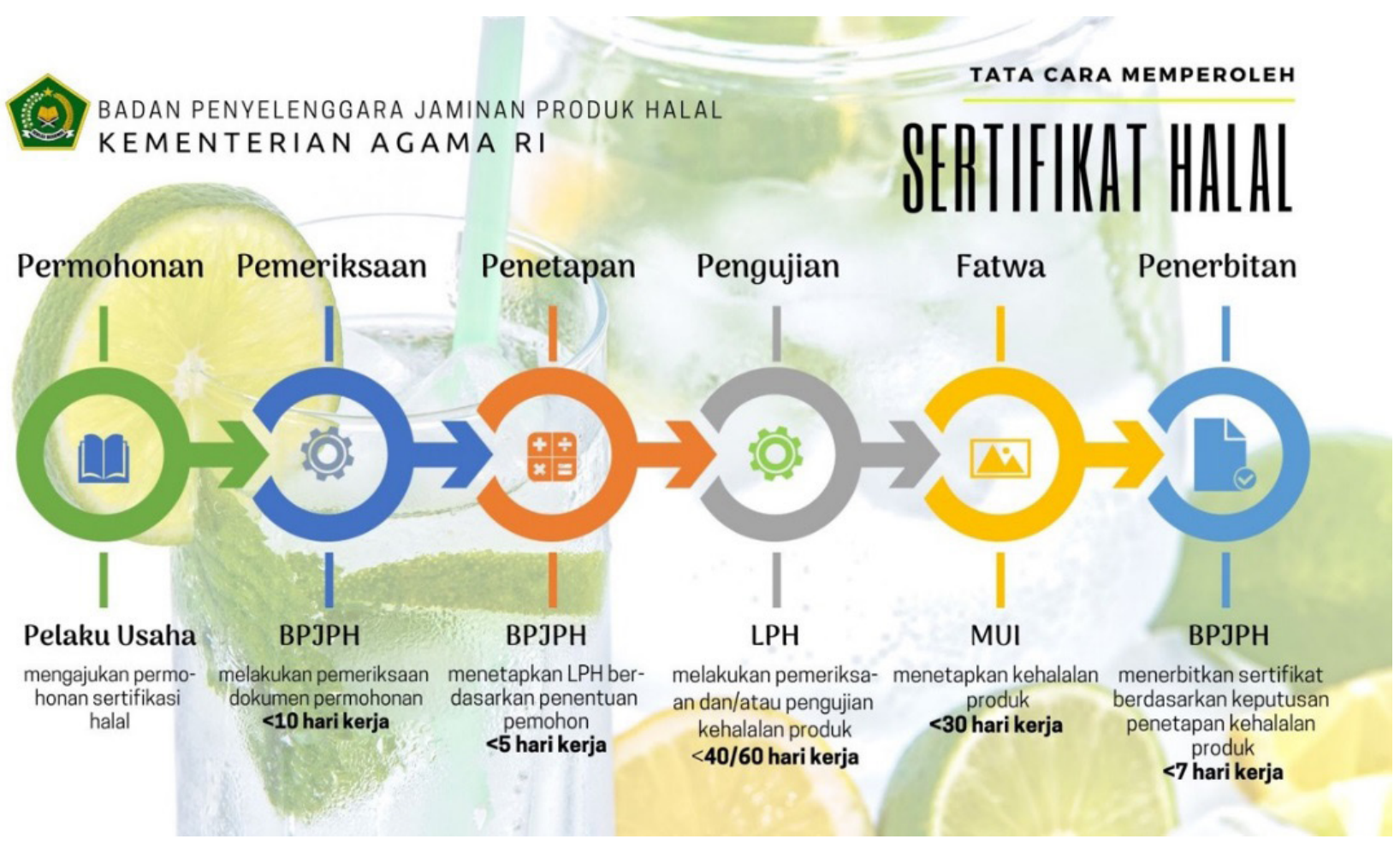

Sumber: Laman halal.go.id

Ketentuan Pasal 33 diubah;

“(1) Penetapan kehalalan Produk dilakukan oleh MUI. (2) Penetapan kehalalan Produk sebagaimana dimaksud pada ayat (1) dilakukan dalam sidang Fatwa Halal. (3) Sidang Fatwa Halal sebagaimana dimaksud pada ayat (2) memutuskan kehalalan Produk paling lama lama 3 (tiga) hari kerja sejak MUI menerima hasil pemeriksaan dan/atau pengujian produk dari LPH. (4) Penetapan kehalalan Produk sebagaimana dimaksud pada ayat (2) disampaikan oleh MUI kepada BPJPH sebagai dasar penerbitan Sertifikat Halal".

Dalam ketentuan tersebut untuk memperoleh sertifikat halal sepenuhnya harus

26 Dikutip melalui laman https://www.halalmui.org/mui14/main/page/prosedur-sertifikasi-halal-mui Persiapan sertifikasi dan Pendaftaran sertifikasi, pada 11/05/2021. 
diakomodir oleh BPJPH dan LPH yang ada diantaranya LPPOM MUI, PT. SUCOFINDO dan Surveyor Indonesia, dalam ketentuan LPH telah diatur pendirian LPH dalam UU Cipta Kerja ${ }^{27}$ terdapat 22 Pasal Undang-Undang Nomor 33 Tahun 2014 tentang Jaminan Produk Halal yang mengalami perubahan dalam undang-undang tersebut. Selain itu, terdapat penambahan 2 Pasal baru. Semuanya meliputi ketentuanketentuan yang berkaitan dengan proses bisnis sertifikasi halal, kerja sama BPJPH, LPH, dan Auditor Halal, Penyelia Halal, Peran Serta Masyarakat, Sertifikat Halal, Label Halal, self declare $^{28}$, dan sanksi administrasi. Sejumlah trobosan pada UU Cipta Kerja sama sekali tidak menghilangkan substansi kehalalan produk. Di dalam proses sertifikasi halal, MUI juga tetap berperan sebagai lembaga yang memiliki kewenangan dalam menetapkan fatwa halal.

Adapun biaya sertifikasi halal oleh pelaku UMK dapat digratiskan melalui berbagai fasilitas pembiayaan, di antaranya melalui APBN/APBD, pembiayaan alternatif untuk UMK, pembiayaan dari dana kemitraan, bantuan hibah pemerintah atau lembaga lain, dana bergulir dan tanggung jawab sosial perusahaan.

Dalam Peraturan Pemerintah Tahun 2021
Tentang Penyelenggaraan Jaminan Produk Halal prosedur pengajuan permohonan sertifikasi halal adalah sebagai berikut; ${ }^{29}$

“Pasal 59 (1) Pelaku Usaha mengajukan permohonan sertifikat halal secara tertulis dalam bahasa indonesia kepada BPJPH melalui sistem elektronik. (2) Permohonan Sertifikat Halal sebagaimana dimaksud pada ayat (1) harus dilengkapi denggan dokumen: a. Data pelaku usaha; b. Nama dan jenis produk; c. Daftar produk dan bahan yang digunakan; dan $d$. Pengolahan produk".

“Pasal 60 Data Pelaku Usaha sebagaimana dimaksud dalam Pasal 59 ayat (2) huruf a dibuktikan dengan nomor induk berusaha atau dokumen izin usaha lainnya. Pasal 61 Nama dan jenis produk sebagaimana dimaksud dalam Pasal 59 ayat (2) huruf b harus sesuai dengan nama dan jenis produk yang akan disertifikasi halal".

"Pasal 62 (1) Daftar Produk dan Bahan yang digunakan sebagaimana dimaksud dalam Pasal 59 ayat (2) huruf c harus merupakan produk dan bahan halal yang dibuktikan dengan sertifikat halal. (2)

27 Ketentuan Pasal 13 diubah sehingga berbunyi “(1) Untuk mendirikan LPH sebagaimana dimaksud dalam Pasal 12, harus dipenuhi persyaratan:

a. Memiliki kantor sendiri dan perlengkapannya;

b. Memiliki Auditor Halal paling sedikit 3 (tiga) orang; dan

c. Memiliki laboratorium atau kesepakatan kerja sama dengan lembaga lain yang memiliki laboratorium.

(2) Dalam hal LPH sebagaimana dimaksud pada ayat (1) didirikan oleh masyarakat, LPH harus diajukan oleh lembaga keagaan Islam berbadan hukum, dan perguruan tinggi swasta yang berada di bawah naungan lembaga keagamaan Islam berbadan hukum atau yayasan Islam berbadan hukum.

(3) Dalam hal suatu daerah tidak terdapat LPH yang didirikan oleh masyarakat sebagaimana dimaksud pada ayat (2), lembaga keagamaan Islam berbadan hukum dan perguruan tinggi swasta yang berada di bawah naungan lembaga keagamaan Islam berbadan hukum atau yayasan Islam berbadan hukum dapat bekerja sama dengan badan usaha milik negara atau Badan Pengawas Obat dan Makanan".

28 Self declare atau pernyataan halal oleh pelaku UMK tersebut harus memenuhi kriteria yaitu menggunakan bahan baku no risk dan bahan pendukung yang sudah pasti kehalalannya. Selain itu, proses produksi terbilang sederhana yang dijalankan oleh pelaku usaha UMK juga harus memenuhi aspek kehalalan.

29 Misbahuddin, Materi Prosedur dan Persyaratan Sertifikat Halal Kabid Bimas Islam Kanwil Kementerian Agama Provinsi Sulawesi Barat. 
Ketentuan sebagaimana dimaksud pada ayat (1) dikeluarkan bagi bahan yang: a. Berasal dari alam berupa tumbuhan dan bahan tambang tanpa melalui proses pengolahan; b. Dikategorikan tidak berisiko mengandung bahan yang diharamkan; dan atau c. Tidak tergolong berbahaya serta tidak bersinggungan dengan bahan haram.

“Pasal 63 Dokumen pengolahan produk sebagaimana dimaksud dalam Pasal 59 ayat (2) huruf d memuat keterangan mengenai pembelian, pnerimaan, penyimpanan bahan yang digunakan, pengolahan, pengemasan, penyimpanan produk jadi, dan distribusi".

"Pasal 64 dalam hal fasilitas produksi yang digunakan untuk memproduksi produk yang diajukan sertifikat halal juga digunakan untuk memproduksi produk yang tidak diajukan sertifikat halal yang tidak berasal dari bahan yang mengandung bahan yang diharamkan, palaku usaha harus menyampaikan dokumen: a. Nama produk; b. Daftar produk dan bahan yang digunakan; c. Proses pengolahan produk; dan d. Pencucian atau penyamakan pada fasilitas produksi yang digunakan secara bersama".

Hubungan antara konsumen dan pelaku usaha, pada dasarnya adalah hubungan hukum yang terbentuk karena ada perjanjian timbal balik antara penjual dan pembeli, perjanjian sewa menyewa, dan lain-lain. Setiap perjanjian yang dibuat secara sah akan mengakibatkan akibat hukum berupa hak dan kewajiban. ${ }^{30}$ Kehalalan suatu produk juga penting bagi pelaku usaha karena memiliki nilai tambah terhadap produk yang akan dijual. Hal ini mengingat bahwa pasar konsumen produk halal terus meningkat setiap tahunnya, baik di pasar domestik maupun pasar internasional. Kehalalan suatu produk juga dapat mendorong tingkat penjualan produk secara signifikan sebab sesuai dengan kebutuhan dan harapan konsumen. Itu berarti akan menaikkan nilai ekonomis produk dan mendorong pertumbuhan ekonomi ke arah yang lebih baik. ${ }^{31}$

\section{Undang-Undang Nomor $\mathbf{1 1}$ Tahun $\mathbf{2 0 2 0}$ tentang Cipta Kerja dalam Mengatur Proses Penerbitan Sertifikasi Halal}

Pengaturan pemeriksaan sertifikasi halal pada awalnya merupakan kewenangan dari Kementerian Agama. ${ }^{32}$ Kementerian Agama telah mengeluarkan Keputusan Menteri Agama No. 518 Tahun 2001 Tentang Pedoman dan Tata Cara Pemeriksaan dan Penetapan Pangan Halal. Selanjutnya ditindaklanjuti dengan Keputusan Menteri Agama No. 519 Tahun 2001 Tentang Lembaga Pelaksana Pemeriksa Pangan Halal, yang menunjuk dan mendelegasikan pelaksanaan sertifikasi halal ke Lembaga Pengkajian Pangan Obat Obatan dan Kosmetika Majelis Ulama Indonesia (LPPOM-MUI).

Dalam perkembangannya, pengaturan sertifikasi halal selama ini masih terkesan sektoral, parsial, inkonsistensi serta tidaksistemik

30 "Tinjauan Pustaka:Beberapa Teori Perlindungan Hak-hak Konsumen dalam E-commerce, (https://e-journal.uajy.ac.id/ cgi/search/archive/advanced, diakses 20/05/2021)

31 Ibid.

32 Pasal 11 ayat (2) Peraturan Pemerintah No. 69 Tahun 1999 Tentang Label Iklan Pangan (Lembaran Negara Republik Indonesia Tahun 1999 Nomor 131, Tambahan Lembaran Negara Republik Indonesia Nomor 3867). 
dan sukarela (voluntery), yang mengakibatkan sertifikasi halal belum mempunyai legitimasi hukum yang kuat. ${ }^{33}$ Selain itu masih banyak produk yang beredar di masyarakat belum semua terjamin kehalalannya, sehingga memerlukan pengaturan yang komprehensif yang meliputi produk barang dan jasa. ${ }^{34}$ Berdasarkan faktor tersebut maka penyelenggaraan sertifikasi halal diatur dalam Undang-Undang Nomor 33 Tahun 2014 Tentang Jaminan Produk Halal (UUJPH).

Pemberlakuan UUJPH ini merupakan salah satu bentuk perlindungan dari negara kepada konsumen Muslim di Indonesia, hal ini sesuai dengan Pasal 29 ayat (2) UUD 1945 mengamanatkan bahwa "negara menjamin kemerdekaantiap-tiappendudukuntukmemeluk agamanya masing-masing dan untuk beribadah menurut agamnya dan kepercayaannya". Untuk menjamin setiap pemeluk agama untuk beribadah dan menjalankan ajaran agamanya, negara berkewajiban memberikan perlindungan dan jaminan tentang kehalalan produk yang dikonsumsi dan digunakan masyarakat, khususnya masyarakat muslim. ${ }^{35}$

Pasal 1 angka 5 UUJPH menyatakan bahwa jaminan produk halal adalah kepastian hukum terhadap kehalalan suatu produk yang dibuktikan dengan sertifikat halal. ${ }^{36}$ Objek sertifikasi halal yang diatur dalam UUJPH lebih luas tidak hanya berupa terkait dengan produk pangan. Hal ini dapat dilihat dari ketentuan Pasal 1 angka 1 UUJPH yang menyatakan bahwa produk yang disertifikasi meliputi barang dan/atau jasa yang terkait dengan makanan, minuman, obat, kosmetik, produk kimiawi, produk biologi, produk rekayasa genetik, serta barang gunaan yang dipakai, dgunakan atau dimanfaatkan oleh masyarakat. ${ }^{37}$

Berdasarkan Pasal5UUJPHpenyelenggaraan jaminan produk halal merupakan tanggung jawab pemerintah. ${ }^{38}$ Dalam hal ini dilaksanakan oleh Kementerian Agama. ${ }^{39}$ Untuk melaksanakan penyelenggaraan jaminan produk halal tersebut pemerintah akan membentuk Badan Penyelenggaraan Jaminan Produk Halal (BPJPH) yang berkedudukan di bawah dan bertanggung jawab kepada Menteri Agama.

BPJPH dalam penyelenggaraan jaminan produk halal diberikan kewenangan untuk menerbitkan dan mencabut sertifikasi halal dan label halal pada produk. Kewenangan ini sebelumnya dilaksanakan oleh LPPOM-MUI. Yang berarti bahwa pemberlakuan UUJPH ini secara kelembagaan nantinya akan terjadi peralihan kewenangan dalam hal penerbitan sertifikasi halal dari LPPOM-MUI kepada BPJPH. Sertifikasi halal merupakan pengakuan kehalalan suatu produk yang dikeluarkan oleh BPJPH berdasarkan fatwa halal tertulis yang dikeluarkan oleh MUI.

BPJPH saat ini sudah ada bahkan telah dikoordinasikan ke Kemenag yang ada ditiap-tiap daerah, bahkan upaya sosialisasi ke masyarakat pun juga telah ada, namun terkendala dalam

33 KN Sofyan Hasan, Kepastian Hukum Sertifikasi dan Labelisasi Halal Produk Pangan, Dinamika Hukum , Volume 14, Nomor 2, Mei 2014

34 Penjelasan Umum Undang-Undang Nomor 33 Tahun 2014 Tentang Jaminan Produk Halal (Lembaran Negara Republik Indonesia Nomor 295, Tambahan Lembaran Negara Republik Indonesia Nomor 5604).

35 Ibid.

36 Pasal 1 angka 5 Undang-Undang No. 33 Tahun 2014 tentang Jaminan Produk Halal.

37 Pasal 1 angka 1 Undang-Undang No.33 Tahun 2014 tentang Jaminan Produk Halal.

38 Pasal 5 ayat (1) Undang-Undang No. 33 Tahun 2014 tentang Jaminan Produk Halal.

39 Pasal 5 ayat (2) Undang-Undang No. 33 Tahun 2014 tentang Jaminan Produk Halal. 
pengaturan dari masing-masing lembaga antara LPPOM-MUI dan BPJPH. Bahkan Pasal 64 UUJPH yang mengamanatkan bahwa pembentukan BPJPH dibentuk paling paling lambat 3 (tiga) tahun sejak UUJPH diundangkan, yakni sejak 17 Oktober 2017.

Pembentukan BPJPH adalah bentuk upaya pemerintah memberikan perlindungan terhadap konsumen juga harus dilihat sebagai suatu sistem. Hukum sebagai suatu sistem merupakan suatu tatanan atau kesatuan yang terdiri dari bagian-bagian atau unsur-unsur yang saling berkaitan, saling berinteraksi satu sama lain, yang terorganisasi dan bekerja sama untuk mencapai tujuan kesatuan itu. Hukum bukanlah sekadar sekumpulan hukum yang masingmasing berdiri sendiri, tetapi harus dilihat dalam kaitannya dengan bagian-bagian lain dalam sistem tersebut. ${ }^{40}$

Peraturan perundang-undangan yang terkait dengan sertifikasi halal ini diatur dalam beberapa ketentuan perundang-undangan sehingga dalam rangka pembentukan BPJPH perlu juga dilaksanakan harmonisasi dan sinkronisasi dengan peraturan perundangundangan terkait. Harmonisasi peraturan perundang-undangan merupakan suatu proses mencari kesesuaian antara peraturan perundang-undangan. Harmonisasi ini idealnya dilakukan pada saat perancangan peraturan perundang-undangan. Adapun sinkronisasi merupakan penyelerasan dan penyelerasian berbagai peraturan perundang-undangan yang terkait dengan peraturan perundang-undangan yang telah ada dan yang sedang disusun yang mengatur suatu bidang tertentu, sinkronisasi dilakukan agar substansi yang diatur dalam produk perundang-undangan tidak tumpang tindih, saling melengkapi (suplementer), saling terkait, dan semakin rendah jenis pengaturannya maka semakin detail dan operasional materi muatannya. ${ }^{41}$ Sinkronisasi dilakukan meliputi sinkronisasi vertikal yaitu mengidentifikasikan apakah suatu perundang-undangan tersebut sejalan apabila ditinjau dari sudut strata atau hierarki peraturan perundangan yang ada, dan sinkronisasi horizontal yakni mengidentifikasi peraturan perundang-undangan yang kedudukannya sederajat dan yang mengatur bidang yang sama. ${ }^{42}$

Penyelenggaraan seritifikasi halal yang selama ini telah dilaksanakan oleh LPPOM-MUI dilaksanakan kerjasama dengan kementerian dan lembaga terkait. ${ }^{43}$ Sehingga dalam rangka pembentukan BPJPH juga perlu dikaji terkait dengan tugas, fungsi dan kewenangan dari kementerian dan lembaga terkait dengan penyelenggaraan jaminan produk halal. Berdasarkan dari uraian diatas maka permasalahan yang diambil yakni bagaimana penyelenggaraan sertifikasi halal di Indonesia terkait Undang-Undang Nomor 33 Tahun 2014 tentang Jaminan Produk Halal (UUJPH) serta bagaimana penguatan lembaga BPJPH dalam menjalankan kewenangannya.

Beberapa ketentuan dalam UndangUndang Nomor 33 Tahun 2014 tentang Jaminan Produk Halal diantaranya pelaku usaha Mikro

40 Sudikno Mertokusumo, Penemuan Hukum: Sebuah Pengantar, Yogyakarta:Liberty, 2006, hlm. 18.

41 Novianto M Hantoro, Sinkronisasi dan Harmonisasi Pengaturan Mengenai Peraturan Daerah Serta Uji Materi Peraturan Daerah Provinsi Bali Nomor 16 Tahun 2009 Tentang Tata Ruang Wilayah Provinsi Bali Tahun 2009-2029.

42 Zaidah Nur Rosidah, Sinkronisasi Peraturan Perundang-Undangan Mengenai Perkawinan Beda Agama, Al-Ahkam, Volume 23, Nomor 1, April 2013.

43 Majelis Ulama Indonesia, Tentang LPPOM-MUI, http://www.halalmui.org/mui14/ diakses 18/05/2020. 
dan Kecil berkewajiban bersertifikat halal dilakukan berdasarkan standar halal yang telah ditetapkan BPJPH. Menurut penulis, kemudahan ini haruslah di barengi dengan sosialisasi kepada masyarakat terkait proses sertifikasi hingga penetapan kehalalan produk, yang terjadi banyak pelaku usaha Mikro dan Kecil yang masih kesulitan terkait alur sertifikasi, jumlah biaya hingga jenis produk atau bahan makanan/ minuman yang tergolong halal.

Bentuk kerja sama antara BPJPH dengan MUI dilakukan dalam hal penetapan kehalalan produk yang diterbitkan MUI dalam bentuk Keputusan Penetapan Halal Produk. Sebagaimana telah diatur sebagai berikut:

Ketentuan Pasal 29 diubah sehingga berbunyi sebagai berikut:

(1) Permohonan Sertifikat Halal diajukan pelaku usaha kepada BPJPH.

(2) Permohonan Sertifikat Halal harus dilengkapi dengan dokumen:

a. Data Pelaku Usaha;

b. Nama dan jenis produk;

C. Daftar produk dan bahan yang digunakan; dan

d. Pengolahan produk.

(3) Jangka waktu verifikasi permohonan sertifikat halal dilaksanakan paling lama 1 (satu) hari kerja.

(4) Ketentuan lebih lanjut mengenai tata cara pengajuan permohonan Sertifikat Halal diatur dalam Peraturan Pemerintah.

Lebih lanjut dalam ketentuan Pasal 30 diubah menjadi:

(1) BPJPH menetapkan LPH untuk melakukan pemeriksaan dan / atau pengujian kehalalan produk berdasarkan permohonan Pelaku
Usaha.

(2) Penetapan LPH sebagaimana dimaksud pada ayat (1) dilakukan dalam jangka waktu paling lama 1 (satu) hari kerja terhitung sejak dokumen permohonan sebagaimana dimaksud dalam Pasal 29 ayat (2) dinyatakan lengkap.

Pemberlakuan UU JPH, menimbulkan beberapa konsekuensi sekaligus tantangan, yakni:

a. Adanya sifat wajib sertifikasi halal yang bertujuan agar adanya kejelasan bahwa yang halal adalah yang benar-benar halal sesuai kriteria halal.

b. Produk yang tidak halal harus dinyatakan tidak halal. Artinya semua produk yang beredar di Indonesia wajib bersertifikat halal. ${ }^{44}$

Setelah Undang-Undang Nomor 11 Tahun 2020 ini disetujui LPH tidak hanya LPPOM MUI tetapi dapat didirikan oleh masyarakat, LPH harus diajukan oleh lembaga keagamaan Islam berbadan hukum, perguruan tinggi swasta yang berada di bawah naungan lembaga keagamaan Islam berbadan hukum atau yayasan Islam berbadan hukum. Selain itu untuk mendirikan LPH telah diatur dalam Pasal 12 Undang-Undang Nomor 33 Tahun 2014 dengan persyaratan: memiliki kantor sendiri dan perlengkapannya, memiliki Auditor Halal paling sedikit 3 orang, dan memiliki laboratorium atau kesepakatan kerja sama dengan lembaga lain yang memiliki laboratorium.

Dalam Peraturan Pemerintah Pasal $24^{45}$ bahwa LPH dapat didirikan oleh Pemerintah dan Masyarakat, perannya pun diatur lebih lanjut dalam PP ini. LPH yang didirikan oleh Pemerintah

44 Tanya Jawab, Konsekuensi Pemberlakuan UU JPH, Jurnal Halal No. 126 tahun 2015, hlm. 18.

45 Peraturan Pemerintah Nomor 39 Tahun 2021 tentang Penyelenggaraan Bidang Jaminan Produk Halal 
meliputi, Kementerian/lembaga, pemerintah daerah, perguruan tinggi negeri atau badan usaha milik negara/badan usaha milik daerah. LPH Kementerian/Lembaga memiliki fungsi sebagai unit kerja atau unit pelaksana teknis kementerian/lembaga. LPH Pemerintah Daerah memiliki fungsi sebagai unit kerja, unit pelaksana teknis, atau perangkat daerah. LPH Perguruan Tinggi Negeri dibentuk oleh Rektor. LPH Badan Usaha Milik Negara/Badan Usaha Milik Daerah adalah bagian dari unit usaha jasa BUMN/BUMD atau anak perusahaan BUMN/BUMD.

Sedangkan LPH yang didirikan oleh Masyarakat harus diajukan oleh lembaga keagaaman Islam berbadan hukum, dan perguruan tinggi swasta yang berada di bawah naungan lembaga keagamaan Islam berbadan hukum atau yayasan Islam berbadan hukum. Apabila dalam suatu daerah tidak terdapat LPH yang didirikan oleh masyarakat dapat bekerja sama dengan BUMN atau Badan Pengawas Obat dan Makanan.

Adapun lingkup kegiatan LPH diatur dalam Pasal 37 meliputi:a. Verifikasi/validasi, b. Inspeksi Produk dan/atau PPH, c. Inspeksi rumah potong hewan/unggas atau unit potong hewan/unggas dan/atau, d. Inspeksi, audit, dan pengujian laboratorium jika dipelukan terhadap kehalalan produk. LPH berperan sebagai pelaksana tugas dari BPJPH dan terlibat langsung dalam proses sertifikasi halal.

Menurut penulis, keberadaan LPH ini dianggap terlalu fleksibel untuk melaksanakan tugas BPJPH, peran lebih banyak antara pelaku usaha dan JPH. Sementara hubungan keduanya erat dengan JPH dan pelaku usaha dan berhak memperoleh informasi, edukasi, dan sosialisasi mengenai sistem JPH, informasi lebih lanjut mengenai pembinaan memproduksi produk halal dan pelayanan untuk mendapatkan sertifikat halal secara cepat, efesien, biaya terjangkau, dan tidak diskriminatif.

\section{Penutup}

Latar belakang pertimbangan pengesahan Undang-Undang Nomor 33 Tahun 2014 tentang Jaminan Produk Halal adalah: bahwa UndangUndang Dasar Negara Republik Indonesia Tahun 1945 mengamanatkan negara menjamin kemerdekaantiap-tiappendudukuntukmemeluk agamanya masing-masing dan untuk beribadah menurut agamanya dan kepercayaannya itu; bahwa untuk menjamin setiap pemeluk agama untuk beribadah dan menjalankan ajaran agamanya, negara berkewajiban memberikan pelindungan dan jaminan tentang kehalalan produk yang dikonsumsi dan digunakan masyarakat; bahwa produk yang beredar di masyarakat belum semua terjamin kehalalannya; bahwa pengaturan mengenai kehalalan suatu produk pada saat ini belum menjamin kepastian hukum dan perlu diatur dalam suatu peraturan perundang-undangan.

Proses legitimasi dari pelaksanaan UndangUndang Nomor 33 Tahun 2014 dilaksanakan sepenuhnya oleh BPJPH dengan prinsip satu pintu untuk memudahkan pelaku usaha menerbitkan sertifikat halal. Sehingga dalam rangka pembentukan BPJPH juga perlu dikaji terkait dengan tugas, fungsi dan kewenangan dari kementerian dan lembaga terkait dengan penyelenggaraan jaminan produk halal. Pembentukan BPJPH adalah bentuk upaya pemerintah memberikan perlindungan terhadap konsumen juga harus dilihat sebagai suatu sistem. Hukum sebagai suatu sistem 
merupakan suatu tatanan atau kesatuan yang terdiri dari bagian-bagian atau unsur-unsur yang saling berkaitan, saling berinteraksi satu sama lain, yang terorganisasi dan bekerja sama untuk mencapai tujuan kesatuan itu. Maka dari itu untuk proses penerbitan sertifikat halal dibutuhkan melalui satu pintu agar semua prosesnya tidak memakan waktu lama dan pelaksanaan yang berbela belit.

BPJPH dalam penyelenggaraan jaminan produk halal diberikan kewenangan untuk menerbitkan dan mencabut sertifikasi halal dan label halal pada produk. Kewenangan ini sebelumnya dilaksanakan oleh LPPOM-MUI. Yang berarti bahwa pemberlakuan UUJPH ini secara kelembagaan nantinya akan terjadi peralihan kewenangan dalam hal penerbitan sertifikasi halal dari LPPOM-MUI kepada BPJPH. Sertifikasi halal merupakan pengakuan kehalalan suatu produk yang dikeluarkan oleh BPJPH berdasarkan fatwa halal tertulis yang dikeluarkan oleh MUI. BPJPH saat ini sudah ada bahkan telah dikoordinasikan ke Kemenag yang ada ditiap-tiap daerah, bahkan upaya sosialisasi ke masyarakat pun juga telah ada, namun terkendala dalam pengaturan dari masingmasing lembaga antara LPPOM-MUI dan BPJPH. Bahkan Pasal 64 UUJPH yang mengamanatkan bahwa pembentukan BPJPH dibentuk paling paling lambat 3 (tiga) tahun sejak UUJPH diundangkan, yakni sejak 17 Oktober 2017. 


\section{DAFTAR PUSTAKA}

\section{A. Buku}

Abdulkadir, Muhammad, Hukum dan Penelitian Hukum, (Bandung: PT. Citra Aditya Bakti, 2004). Arifin, Firmansyah, dkk, Lembaga Negara dan Sengketa Kewenangan Antarlembaga Negara, Cet.

I, (Jakarta: KRHN, 2005).

Asshiddiqie, Jimly, Perihal Undang-Undang, (Jakarta: Konstitusi Press, 2006). , Konstitusi \& Konstitualisme Indonesia, (Jakarta: Sinar Grafika, 2018). Menuju Negara Hukum yang Demokratis, (Jakarta: Sekretariat Jendral dan Kepaniteraan Mahkamah Konstitusi, 2009). Perihal Undang-Undang, (Jakarta: Konstitusi Press, 2006). Perkembangan dan Konsolidasi Lembaga Negara Pasca Reformasi, 2006.

Daud Ali, Mohammad, Hukum Islam, (Jakarta: Raja Grafindo Persada, 2011).

Hidjaz, Kamal, Efektifitas Penyelenggaraan Kewenangan Dalam Sistem Pemerintahan Daerah Di Indonesia, (Makassar: Pustaka Refleksi, 2010).

HR, Ridwan, Hukum Administrasi Negara, (Jakarta: PT. Raja Grafindo Persada, 2013). Indroharto, Usaha Memahami Undang-Undang tentang Peradilan Tata Usaha Negara, (Jakarta:Pustaka Harapan, 1993).

Ibrohim, Johny, Teori dan Metodologi Penelitian Hukum Normatif, (Malang: Bayu Publishing, 2006).

K.C. Wheare, Modern Constitutions, London, (Oxford University Press, 1997).

M. Mangunsong, Parlin, Konvensi Ketatanegaraan Sebagai Salah Satu Sarana Perubahan UUD, Alumni, (Bandung, 1992).

Mahfud MD, Moh, Pergulatan Politik dan Hukum di Indonesia, (Yogyakarta: Gama Media, 1999). , Politik Hukum di Indonesia, Cet. 1, (Jakarta: LP3ES, 1998).

Manan, Bagir, Wewenang Provinsi, Kabupaten, dan Kota dalam Rangka Otonomi Daerah, Fakultas Hukum Unpad, (Bandung, 2000).

Mahmud Marzuki, Peter, Penelitian Hukum, (Jakarta: Kencana Prenada Media Grup, 2011).

M. Hadjon, Philipus, dan Tatiek Sri Djatmiati, Argumentasi Hukum, (Yogyakarta: Gajah Mada University Press, 2005).

Nurmayani, Hukum Administrasi Daerah, Universitas Lampung Bandar Lampung, 2009.

Saleh, Ismail, Demokrasi, Konstitusi, dan Hukum, (Jakarta: Depkeh RI, 1998).

Sudibyo, Agus, Demokrasi dan Kedaruratan, (Serpong: Marjinkiri, 2019).

Soekanto, Soerjono, Pengantar Penelitian Hukum, Cet. 3, (Jakarta:UI Press, 2012).

Trisulo, Evy, Kajian Kelembagaan Sekretariat Komisi Informasi, (Jakarta: Komisi Informasi Pusat RI Graha PPI, 2014).

Wahjono, Padmo, Masalah Ketatanegaraan Indonesia Dewasa Ini, (Jakarta: Ghalia Indonesia, 1984). 


\section{B. Makalah/Artikel/Prosiding/Hasil Penelitian}

Abdul Halim, Membangun Teori Politik Hukum Islam di Indonesia, Fakultas Syariah dan Hukum

Syarif Hidayatullah Jakarta, Ahkam: Vol. XIII, No. 2, (Juli 2013).

Bani Syarif Maula, Politik Hukum dan Positivisasi HukumIslam di Indonesia (Studi Tentang Produk

Hukum Islam Dalam Arah Kebijakan Hukum Negara), Istinbath: Jurnal Hukum Islam Vol. 13,

No.2, (Desember 2014).

Ralang Hartati, Peran Negara Dalam Pelaksanaan Jaminan Produk halal, Fakultas Hukum Universitas Tama Jagakarsa, ADIL: Jurnal Hukum Vol. 10 No.1

Abdul halim, Membangun Teori Politik Hukum Islam, Ahkam: Vol. XIII, No. 2, (Juli 2013).

C. Internet

"Menelusuri Asal Usul Konsep Omnibus Law", https://www.hukumonline.com/berita/baca/ It5e2c1e4de971a/menelusuri-asal-usul-konsep-omnibus-law/, (Diakses pada 12 Maret 2020) "Jaminan Produk Halal", https://www.jogloabang.com/pustaka/uu-33-2014-jaminan-produkhalal (Diakses Pada 16 Maret 2020)

\section{Peraturan Perundang-Undangan}

Lembaran Negara Pasal 7 Undang-Undang Nomor 33 Tahun 2014 Tentang Jaminan Produk Halal Lembaran Negara Pasal 1 Undang-Undang Nomor 33 Tahun 2014.

Lembaran Negara Undang-Undang Nomor 11 Tahun 2020 Tentang Cipta Kerja

Lembaran Negara Pasal 1 Ayat 2 Undang-Undang Nomor 12 Tahun 2011 Tentang Pembentukan

Peraturan Perundang-undangan. 


\section{BIODATA PENULIS}

Indah Fitriani Sukri, lahir di Sungguminasa Kabupaten Gowa Provinsi Sulawesi Selatan. Penulis merupakan aktifis di organisasi eksternal kampus HMI Komisariat Hukum UMI Makassar, Ikatan Mahasiswa Magister Hukum UI, dan PBHI Wilayah Sulsel. Penulis merupakan alumni dari Fakultas Hukum Universitas Muslim Indonesia Makassar (Strata satu, SH Tahun 2019) dan saat ini penulis merupakan Mahasiswi Aktif Pascasarjana Universitas Indonesia Jurusan IImu Hukum Prodi Hukum Kenegaraan dan fokus menyelesaikan studi program magister hukum.

Penulis pernah magang di Perhimpunan Bantuan Hukum dan HAM Wilayah Sulawesi Selatan, dan pernah aktif di berbagai organ Mahasiswa baik Intra maupun Ekstra. Ketertarikan penulis terhadap dunia penelitian dan penulisan karya tulis ilmiah membawanya mengirimkan beberapa naskah tulisan ke Media Cetak (Kolomnis Opini) ataupun mengirimkannya ke surel untuk diterbitkan sebagai bahan bacaan. Penulis memiliki motto bahwa menulis adalah bekerja untuk keabadian. 